\title{
Cooperative Learning Method for Improving Learning- Outcome in Digital Signal Processing Course
}

\author{
Rudy Fernandez ${ }^{1 *}$ Mumuh Muharram ${ }^{1}$ \\ ${ }^{1}$ Electrical Engineering Department, Universitas Andalas, Limau Manis, Padang 25166, Indonesia \\ *Corresponding author.Email: rfernandez@eng.unand.ac.id
}

\begin{abstract}
Digital Signal Processing (DSP) is a mandatory course for students of the Electrical Engineering Department in Universitas Andalas. The course is to provide an understanding of concepts of digital signal processing as well as its application. Teacher-centred Learning was used to deliver the course materials, which lead to the course learning outcome (CLO) not sufficiently fulfilled. This article is aimed at describing the implementation of cooperative learning method in DSP class. The objective of the research is to identify the effectiveness of the method in achieving the expected learning outcome in learning DSP. The study is conducted at the DSP class of Electrical Engineering Department at Andalas University. The data are collected by giving self-assessment, homework, a project and exams as tools for assessing the CLO. The analysis is done by relating the concept proposed with the target set in the semester learning plan. The result of the study is presented descriptively.
\end{abstract}

Keywords: Course learning outcome, Cooperative learning method, Student-centred learning, Teachercentred learning

\section{INTRODUCTION}

Digital Signal Processing (DSP) Course is a mandatory course in the Curriculum of Electrical Engineering Department in Universitas Andalas (Unand). The course is conducted in the $6^{\text {th }}$ semester. All student in the department has to take the required course, which is Signal and System before taking the DSP course [1].

Department of Electrical Engineering Unand, since 2016 has implemented a curriculum tailored to the high education curriculum (K-PT) based on learning outcomes. The learning outcomes are based on the Indonesian National Qualification Framework (KKNI) and National Higher Education Standards (SNPT) and Indonesian Accreditation Board for Engineering Education (IABEE).

Some of student learning outcomes (SLO) applied in Department of Electrical Engineering are: (1) Mastering the theoretical concepts of engineering sciences, engineering principles and engineering design that are necessary for the analysis and design in electrical power systems, telecommunications systems and control systems.

(2) Able to make a proper decision in the context of problem-solving in the area of expertise based on the analysis results from information and data. (3) Able to apply mathematics, science, and engineering principles to solve complex engineering problems in electrical power systems, telecommunication systems and control systems [12].

These SLOs are derived as the course learning outcome (CLO) for DSP course. The CLOs of DSP are:

(1) A student has the ability to convert the analogue system to the digital system and vice versa. (2) A student has the ability to analyze digital systems in the $\mathrm{z}$-domain.

(3) A student has the ability to use mathematical tools in discrete systems. (4) A student has the ability to design a filter to meet frequency-domain specifications.

As a mandatory course, DSP is attended by 130 students on average. Hence, it was quite challenging to gain the CLO of the course while the learning method is based on the traditional learning method. In the traditional learning method, the most active person in the classroom is the lecturer so-called teacher-centred learning (TCL). One of the disadvantages of this method is that students become inactive in the classroom resulting in the number of students who have low-grade is dominant. It means that the CLOs are not gained as expected. The grade record for DSP course from the last two academic years confirms about it. 
Due to the advantage of the TCL, researchers have shown that group learning leads to academic and cognitive benefits. Group learning promotes student learning and achievement [3-4] and promote greater transfer of learning [5]. Group learning also aids in the development of social skills such as communication, presentation, problemsolving, leadership, delegation and organization [6].

In this study, we propose to implement cooperative learning method in the DSP course to improve set CLOs this year (Academic Year 2020/2021). Consequently, the grade of the students taking the course increased.

\section{METHODS}

The research is conducted in all of DSP Classes which are Class A, B, and C in Electrical Engineering Department of Andalas University. About 133 students are taking this course. These students are divided into groups. Based on the student list obtained from the academic portal, the combination and variation of members of a group are determined.

The rules of group division include: (a) Group division is carried out by the lecturers to avoid the formation of a group based on the personal closeness of the student participants. (b) At least in each group, there is one female student given their relatively small number in the class. (c) Students from the same cohort are distributed evenly for each group formed in a class. So the number of groups formed ranges from 9-10 groups with the number of members ranging from 4-5 students.

The data are taken by giving homework, assignment, midtest, and final test as tools for assessing the course learning outcome. Furthermore, self-assessment is also used to enrich the data. The analysis is done by calculating the percentage of the number of students who gain a score above the set target. The target score is that every student has to pass the minimum score of 55 for each CLO. The score of 55 is based on equivalence value for " $\mathrm{C}$ " in Academic Regulation of Andalas University. The target percentage for number of students with a passing score in each CLO is 55 $\%$. The result of summative assessment comes into the indicator. Finally, the result of the analysis is descriptively presented.

\section{RESULTS AND DISCUSSION}

Based on the data gathered from self-assessment, homework and assignment, we can describe the soft skill of the students in the class like personal responsibility, teamwork, and communication skill. These three soft skills are illustrated in figure 1,2 and 3.

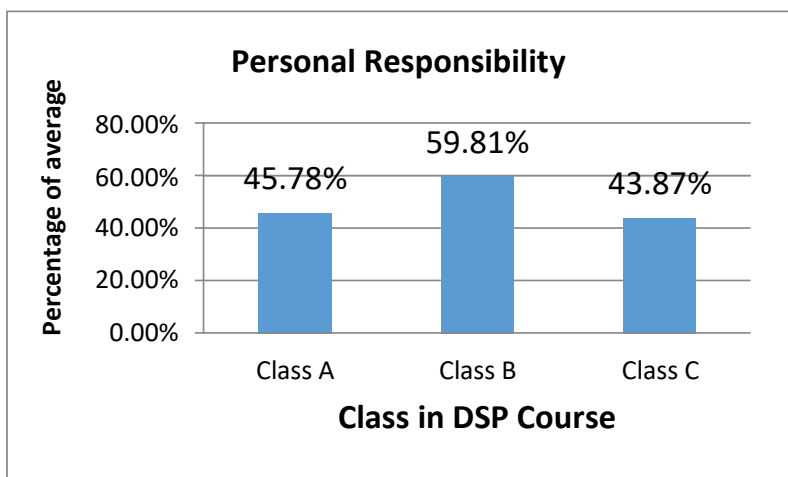

Figure 1 Percentage of the average score on personal responsibility in a group.

Figure 1 shows that students in class $\mathrm{C}$ have the lowest average score, which is $43.87 \%$ on personal responsibility in the group. Class B is the top scorer and the second by Class A with the average score of $59.81 \%$ and $45.78 \%$ respectively.

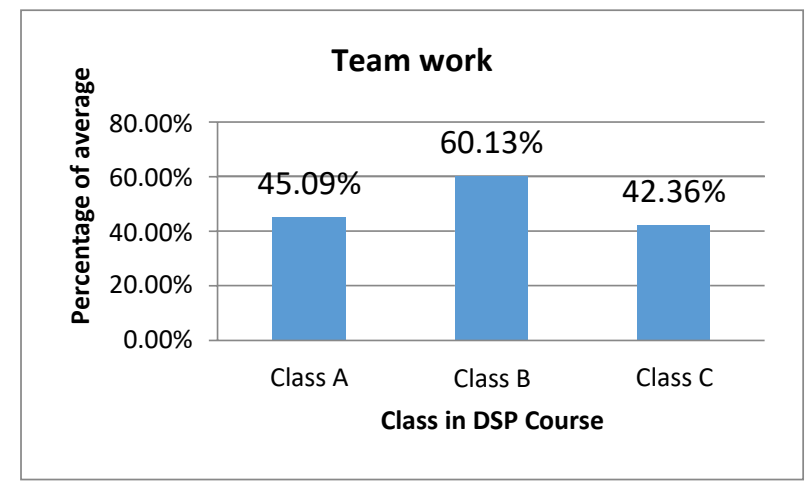

Figure 2 Percentage of the average score on teamwork in a group.

Students in Class B have the highest average score which is $60.13 \%$ on teamwork. At the same time, Class $\mathrm{A}$ and Class $\mathrm{C}$ are the second and the last with the average score of $45.09 \%$ and $42.36 \%$ respectively.

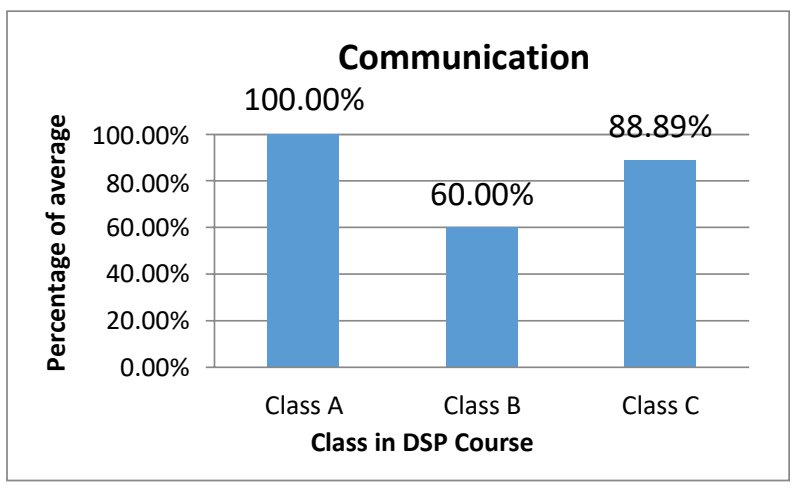

Figure 3 Percentage of the average score on communication in a group. 
On communication skill in figure 3, students in Class B have the lowest average score. Students in Class A have the highest average score which is $100 \%$ and followed by students in Class $\mathrm{C}$ which is $88.89 \%$.

Performance of the students in achieving CLOs is determined and assessed in the Assignment, Final Project, Mid Test and Final Test. Assessment on the Assignment determined the achievement of the student in CLO 1. CLO 2 determined by the assessment on the Final Project. Mid Test and Final test are assessed for students performance in achieving CLO 3 and CLO 4, respectively.

All of the results of the assessment on CLOs are summarized in Figure 4. The score is presented in percentage as planned on semester leaning plan for DSP course.

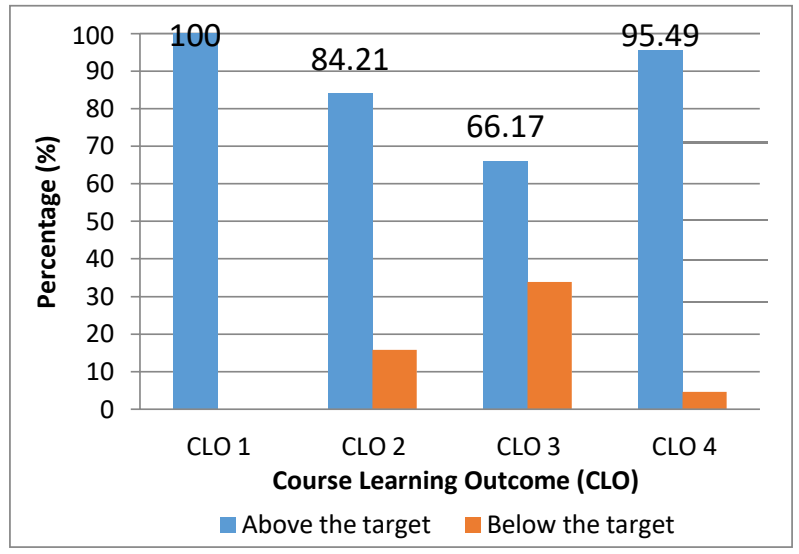

Figure 4 Percentage of achievement on different CLOs.

Assessment on CLO 1 has the highest percentage, which is $100 \%$ among other assessments. This CLO 1 is followed by CLO 4 that shows the ability of a student to design a filter to meet frequency-domain specifications. The percentage in CLO 2 is 95.49\%. CLO 2 and CLO 3 are the third and the fourth with a percentage of $84.21 \%$ and $66.17 \%$ respectively.Overall, the percentage of each CLOs are above the target. The target for each CLO is set at $55 \%$. At the same time, the minimum percentage is $66.17 \%$.

Every score gained by students on all assessment form in the academic year 2019/2020 is accumulated into their final score. The score is converted into grade in Alphabet, as seen in Figure 5.

The grade from this academic year (2019/2020) is compared with the academic year (2018/2019). Figure 5 shows that the percentage of students who passed the DSP course is $95.48 \%$. There is an increment of $15.64 \%$ compared to the last year.

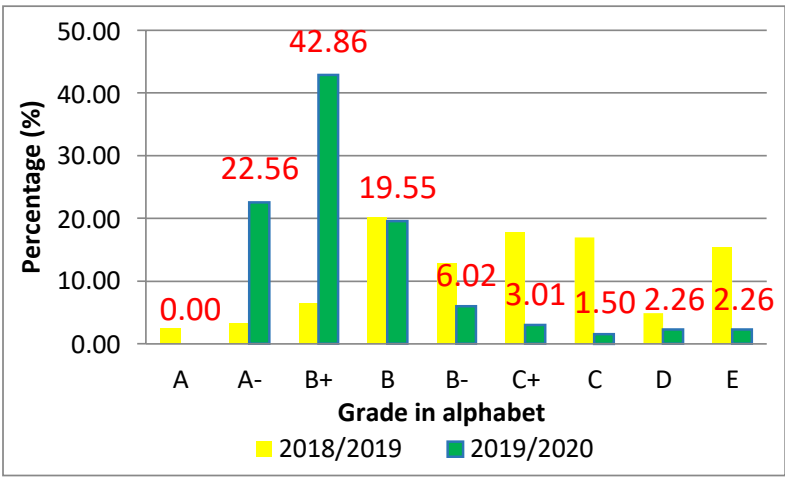

Figure 5 The comparison of the grade distribution between two academic years in the DSP course

The percentage of students in the academic year of 2019/2020 who got grade A- and B+ is also increased. The increment in total is $55.74 \%$ higher than in the last year. The increment is also followed for grade A-.

\section{CONCLUSION}

This study concluded that cooperative learning method in DSP course has shown an effective performance in improving course learning outcome. All the CLO achieves above the target with at least $66.17 \%$. This is also confirmed by the number of students passing the course this year increased compared to the last year.

\section{ACKNOWLEDGMENT}

This work was supported by PPMP - LP3M

Universitas Andalas Grant, 2020.

\section{REFERENCES}

[1] Kurikulum Program Studi Sarjana Teknik Elektro Tahun 2016.

[2] Peraturan Menteri Pendidikan dan Kebudayaan Republik Indonesia No 73 Tahun 2013 tentang Penerapan Kerangka Kualifikasi Nasional Indonesia bidang Pendidikan Tinggi, 2013.

[3] Cockrell, K.S., Hughes - Caplow, J.A. and Donaldson, J.F. A context for learning: collaborative groups in problem-based learning environment, Review of Higher Education, 2000.

[4] Johnson, D.W., Johnson, R. and Stanne, M. Cooperative Learning Methods: A Meta-analysis. Minneapolis: University of Minnesota, 2000.

[5] Brandon, D.P. and Hollingshead, A.B. Collaborative learning and computer-supported groups, Communications Education, 1999.

[6] Cheng, W. and Warren, M. Making a difference: using peers to assess individual students' contributions to a group project, Teaching in Higher Education, 2000 